\title{
Perception on ethical climate and individual job performance of bank employees
}

\author{
HOANG HAI YEN \\ University of Economics HCMC - yenhh@yahoo.com
}

ARTICLE INFO

Article history:

Received:

Mar. 2, 2017

Received in revised form:

July 4, 2017

Accepted:

Oct. 25,2017

Keywords:

Ethical climate

Egoism

Benevolence

Principle ethical climate

Individual job performance

\section{ABSTRACT}

This study investigates the impacts of various organizational ethical climates (egoism, principle, benevolence) on individual performance of bank employees. The research is conducted on the sample consisting of employees working in the commercial banks with less than $50 \%$ of state capital in Vietnam. The total of 364 valid complete questionnaires are input into SPSS database for processing. The research model and hypotheses are tested using the technique of Structural Equation Modeling. The research results show that different perceptions on organization ethical environment would lead to different individual performance. When the employee perceives his/her ethical environment as Eegoism, productivity, quality, and work efficiency would be significantly higher than those of the environments of benevolence. No impact, however, is identified of principle ethical environment on employees' performance. 


\section{Introduction}

In the banking system, business ethics plays an important role in developing the internal relationship (among staffs, departments) and external relationship (with customers, business partner, and the community) (Icke et al., 2011). Business ethics is not only the option of organization behavior, but also the option, behavior, and responsibility of the staff to themselves, to the bank, and to customers and society (Jaseviciene, 2012). However, business ethics in the banking system did not receive due attention from the bank itself and researchers (Koslowski, 2011). Very few banks had guides or sets of criteria on internal ethical standards, so staff and department usually gauge the overall social responsibility and benefits of the bank in making decision (Hoepner, 2010).

Most earlier studies examined the direct or indirect influence of ethical climate on organizational performance (Hoang, 2015). Studies of the influence of organizational ethical climate mostly conducted on job satisfaction (Elci et al., 2006; Ambrose et al., 2008; Tsai and Huang, 2008; Deshpande, 2011; Goldman and Tabak, 2010); loyalty and organization commitment (Cullen et al., 2003; Ambrose et al., 2008); and knowledge management and risk taking (Hoang, 2015). There is still a gap in researching the impact of organizational ethical climate on individual performance. Hoang (2015) confirmed the indirect relationship between the ethical climate and individual performance mediated by risk taking propensity and knowledge management. However, the influence of different types of ethical climate on individual performance was not yet investigated. Meanwhile, positive individual performance not only brings better business results but also reduces turnover (Ambrose et al., 2008; Elci et al., 2009) or increases employee satisfaction with an organization (Tsai and Huang, 2008; Deshpande, 2011). Moreover, the evaluation of individual performance provides motivation to employees and information to management in decision making process (Orpen, 1995; George et al., 1999). In other words, the evaluation of individual performance provides a clear and applicable guide in the analysis of business performance and in the identification of problems related to performance. Based on this guide, management could select appropriate strategies and optimal solutions to any arising problem (Deshpande, 2011). Both of the above purposes are closely intertwined as one of the ways for management to motivate employees is the decision made on income distribution according to the level of individual performance.

This study is the response to the limitation of the previous study of Hoang (2015) by developing and testing the model of impact of various ethical climates on individual performance. The paper examines the impact of perception of ethical environment on individual productivity, quality, and efficiency of bank employees.

\section{Literature review and research methodology}

\subsection{Individual performance}

There are different perspectives on individual job performance. Babin and Boles (1998) considered "individual performance" as "a measure of productivity of an individual in comparison to those of colleagues" (cited in Gibbs et al., 2013). Allen and Griffeth (1999) argued that "individual performance measures his/her performance against the expectation or predefined standards of the organization" (cited in Gibbs et al., 2013), whereas according to Som et al. (2014), "performance is kind of personal behavior to achieve the organization's 
expectation and regulations as well as personal basic desires". Individual performance is a multidimensional concept which includes individual productivity, individual quality, and individual efficiency (Bontis \& Serenko, 2007).

\subsection{Ethical climate}

The theory of ethical environment of an organization was first proposed by Victor and Cullen in 1988 by combining the research on activities of ethical development of Kohlberg (1984) and activities of organizational sociology of Schneider (1983). Victor and Cullen (1988) defined ethical climate as “a firm's ethical climate is comprised share perceptions of what constitutes right or appropriate behavior, and provides a framework for ethical decision making."

Although there are certain limitations (Mayer et al., 2009), the concept of ethical climate of Victor and Cullen (1988) has since then been utilized in the majority of studies (Hoang, 2015). In this study the concept of ethical climate of Victor and Cullen (1988) is used again.

There are two perspectives of ethical climate following ethical philosophy and following sociology (Victor \& Cullen, 1988). The one following ethical philosophy classifies ethical climate by the decisions of individuals and organization: for the benefits of whom? (Mayer, 2009). The one following sociology concerns who or what influences the ethical decisions of individuals and organization. Combining the two perspectives, there are three types of ethical climate namely egoism, benevolence, and principle (Victor \& Cullen, 1988).

Egoism ethical climate is such that all controlling criteria of the organization aim at maximizing the benefits of the organization or toward the behaviors for individual benefits (Victor \& Cullen, 1988).

Benevolence ethical climate is such that all control criterias focus on maximizing benefits of internal people (employees, other members of the organization) and external people (investors, other partners) (Victor \& Cullen, 1988). In organizations where benevolence ethical tendency prevails, all decisions have to bring benefits to the largest number of people including ones inside and outside the organization (Cullen et al., 2003).

The principle ethical climate is such that the control system focuses on the laws and rules, policies, procedures, and regulations. All decisions within the organization need to refer to and comply with its rules and regulations.

\subsection{Hypotheses}

In an organization, the ethical climate is as important as financial results (Icke et al., 2011). The review of literature shows that previous studies focused mainly on examining the influence of ethical climate on organizational performance. For individual performance, some studies confirmed the indirect impact of ethical climate on individual performance mediated by job satisfaction and organizational commitment. For instance, these can be observed from the studies of Deshpande (1996), Joseph et al. (1997), Koh and Boo (2001), Elci et al. (2009), Goldman et al. (2010), Martin and Cullen (2006), and Tsai and Huang (2008).

There were different impacts of each of the ethical environments on satisfaction. It was documented that the benevolence environment negatively influences the employees' satisfaction with the supervisors and managers (Joseph et al., 1997; Elci et at., 2009). Meanwhile, the egoism environment or principle one positively influences such satisfaction. Similarly, the research study of Tsai and Huang (2008) indicated that the management attempted to create a benevolence or principle environment and at the same time avoided the development of 
egoism environment in their organizations.

Other studies identified the impact of job satisfaction on individual performance. The studies include those of Hartline and Ferrell (1996), Yoon et al. (2001), Deery (2008), Ashill et al. (2008), Mulki et al. (2008), Lim and Teo (2010), Aboelmaged and Subbaugh (2012), and Gibbs et al. (2013).

Similarly, the studies of Ambrose et al. (2008), Mulki et al. (2008), Sims and Keon (1997), and Stewart et al. (2011) revealed the relationships between different types of ethical environment with intention to resign and organizational commitment. These findings indicate that in the egoism environment the employees would have strong intention to quit, and weak organizational commitment. They would have higher commitment when they worked in the benevolence environment or principle environment.

Some other studies were on the impact of organizational commitment on individual performance. These include Jaramillo et al. (2012), Costigan et al. (2006), Deery (2008), Carver and Candela (2008), Meer and Ringdal (2009), and Lim and Teo (2010).

Figure 1 summarizes the studies identifying the impact of ethical environment on individual performance mediated by job satisfaction and organizational commitment.

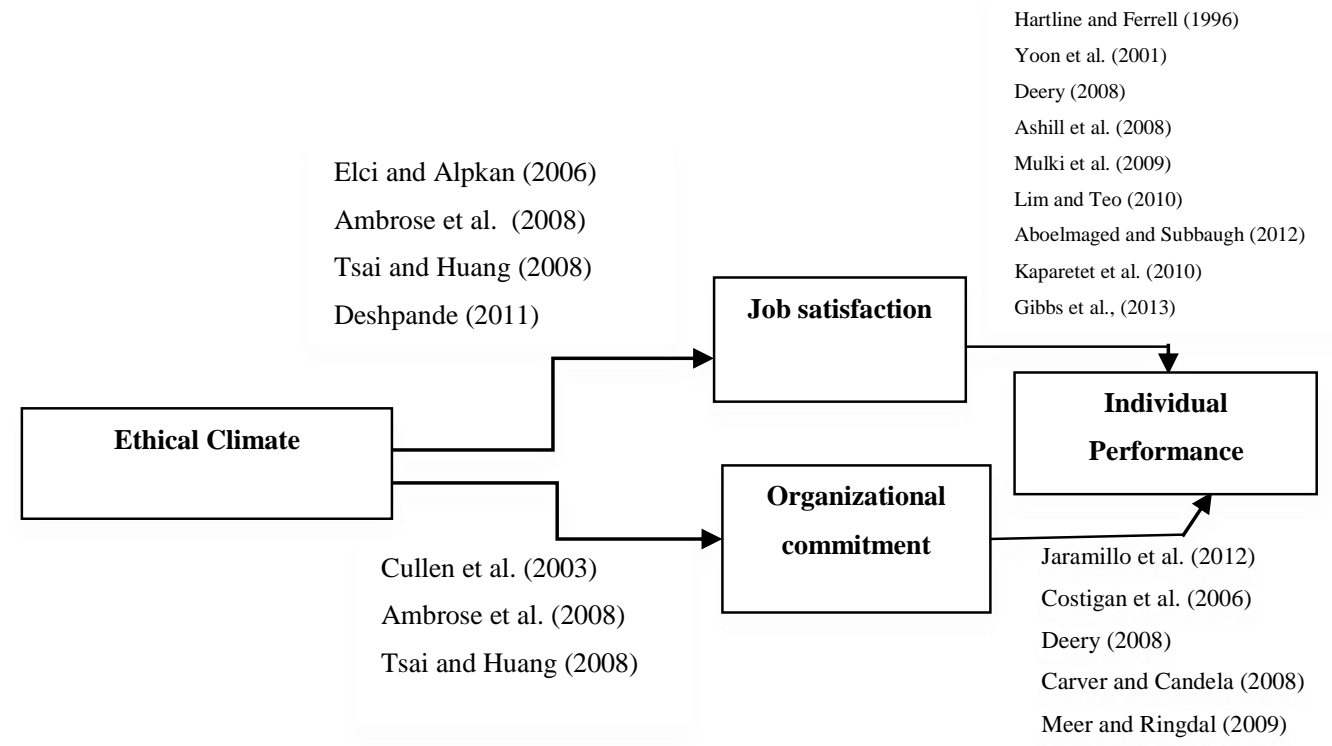

Figure 1. The indirect impact of ethical environment on individual performance

Therefore, results from the mentioned studies indicate that organizations can change the ethical climate to improve satisfaction, organizational commitment, improving knowledge management and accepting higher risks so as to influence the employees' personal performance. Then, if there is no need for concerning the employees' satisfaction, commitment, managers can focus on managing the ethical climate alter the employees' personal performance? Or if there is considerable, direct influence of ethical climate on personal performance then the management can focus on the climate so as to improve individual performance without 
compromising resources to other areas to improve satisfaction, commitment, knowledge management and risk-taking propensity. The author proposes the hypothesis of the direct impact of perception on ethical climate and then on individual performance. The three basic ethical climates (egoism, benevolence, and principle) as per classification of Victor and Cullen (1989) are to be examined to see whether they have any impact and how they have impact on employees' individual performance. There are nine hypotheses on the impact of each climate on productivity, quality, and efficiency of work of the bank employees.

Hypothesis HI: the perception on ethical climate as egoism would improve the individual performance of bank employees.

Individual performance is measured through productivity, quality, and efficiency. Three subhypotheses are developed:

Hypothesis Hla: the perception on ethical climate as egoism would improve the productivity of bank employees.

Hypothesis H1b: the perception on ethical climate as egoism would improve the work quality of bank employees.

Hypothesis Hlc: the perception on ethical climate as egoism would improve the efficiency of bank employees.
Hypothesis H2: the perception on ethical climate as benevolence would improve the individual performance of bank employees.

Sub-hypotheses:

Hypothesis H2a: the perception on ethical climate as benevolence would improve the productivity of bank employees.

Hypothesis $H 2 b$ : the perception on ethical climate as benevolence would improve the work quality of bank employees.

Hypothesis H2c: the perception on ethical climate as benevolence would improve the efficiency of bank employees.

Hypothesis H3: the perception on ethical climate as principle would improve the individual performance of bank employees.

Hypothesis H3a: the perception on ethical climate as principle would improve the productivity of bank employees.

Hypothesis H3b: the perception on ethical climate as principle would improve the work quality of bank employees.

Hypothesis H3c: the perception on ethical climate as principle would improve the efficiency of bank employees.

The research model is proposed as in Figure 2.

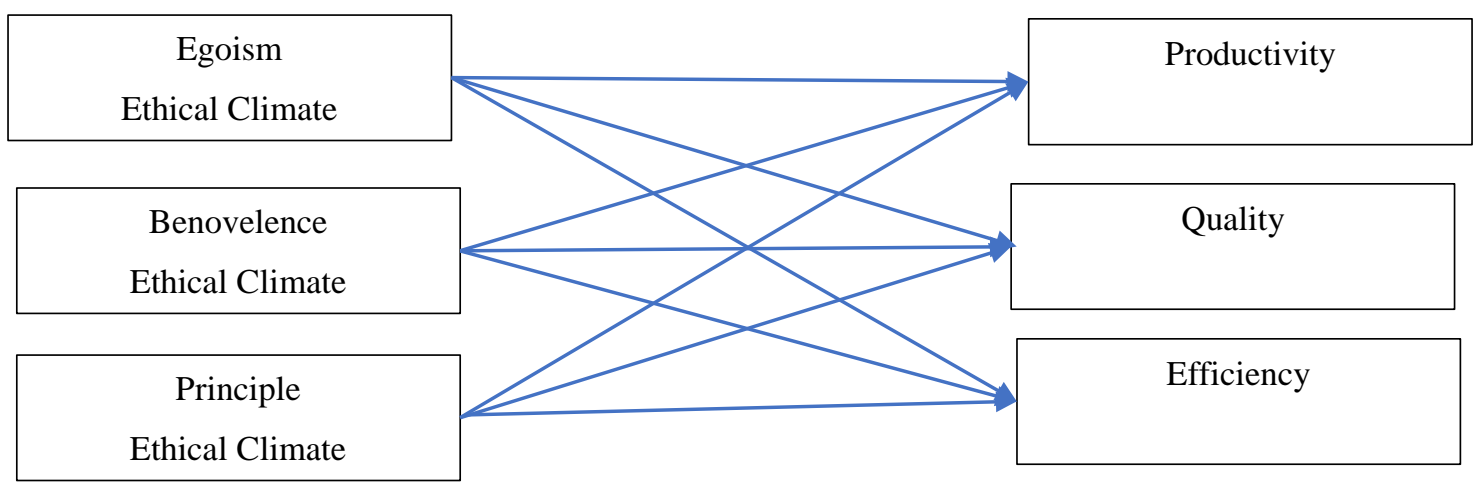

Figure 2. The research model 


\section{Research methodology}

Quantitative methods are used in the formal research in order to confirm the measurement scale and test the hypotheses as well as the research model. The variables measuring the concepts are tested using the function of Confirmatory Factor Analysis of the software AMOS 18. The research model and hypotheses are tested using the Structural Equation Modeling technique.

Performance evaluation provides the basis for motivating the employees (Orpen, 1995; George \& Jones, 1999) and information for management (Deshpande, 2011). Employee's individual performance can be evaluated by the organization, peers, and supervisors or selfconducted. The study receives evaluation records of the commercial banks' employees from different criteria. The bias of self-evaluation of individual performance was highlighted by Kararete et al. (2010), Yavas et al. (2010), Yavas et al. (2013), and Gibbs et al. (2013) as one of the limitations of their studies. However, the bias during the process of self-evaluation was much reduced when it is administered on an anonymous basis or it does not require the person to provide personal information. Anonymity and absence of personal information help improve the value and reliability of self-evaluation (Yavas et al., 2013). Besides, Gibbs et al. (2013) maintained that self-evaluation of individual performance provides the most accurate information as only the very person himself/herself knows exactly what s/he did (job performance) and his/her perception of the job (satisfaction) and organization (organizational commitment).

The performance can be measured based on effectiveness, satisfaction, and productivity (Chiu, 2004). Kulkarni et al. (2006, 2007) and Bontis and Serenko (2007) evaluated the individual performance based on their perception about their improvement in terms of quality, productivity, and efficiency. Being different from the approach of Chiu (2004), in which the

\section{Table 1}

Observing variables of individual performance

\begin{tabular}{ll} 
Code & Variables \\
\hline NS1 & I always meet or exceed work targets \\
NS2 & I can finish all assigned work earlier than deadlines \\
NS3 & I can reduce the time needed to complete daily work \\
HQ1 & My performance always exceeds the targets that the supervisors give \\
HQ2 & I had ideas and suggestions useful for the bank \\
HQ3 & I did not receive any complaint from the customers \\
CL1 & I have never been late at work or caused anything negative because of my \\
& negligence \\
CL2 & I have never received any negative feedback about my performance \\
CL3 & My superiors have always been satisfied with my performance \\
\hline
\end{tabular}




\section{Table 2}

Observing variables of egoism ethical climate

\begin{tabular}{ll}
\hline Code & Variables \\
\hline In my bank: & \\
VK1 & Employees are expected to do whatever necessary for the benefit of the bank \\
VK2 & Performance is considered not satisfactory if harmful to the benefits of the bank \\
VK3 & Decisions considered good or bad are foremost based on the their contribution to \\
the benefits of the bank & At work, all employees care for the benefits of the bank \\
VK5 & Everyone highly appreciate esprit de corps
\end{tabular}

measurement scale was used for the managers evaluating their staff's performance, in the work of Kulkarni et al. (2007), Bontis and Serenko (2007), and Anantamula (2007), the employees evaluate their performance themselves. The author chooses to re-use the observing variables of personal performance of Kulkarni et al. (2006, 2007), Bontis and Serenko (2007), and Anantamula (2007). The measurement scale includes nine observing variables in total. Each component of productivity, quality, and efficiency is measured by three variables.

The measurement scale of egoism ethical climate includes five observing variables as proposed by Victor and Cullen (1993).

\section{Table 3}

Observing variables of benevolence ethical climate

\begin{tabular}{|c|c|}
\hline Code & Variables \\
\hline \multicolumn{2}{|c|}{ In my bank: } \\
\hline QT1 & $\begin{array}{l}\text { Individual interests are the big } \\
\text { concern of the bank }\end{array}$ \\
\hline QT2 & $\begin{array}{l}\text { The leaders really care about the } \\
\text { common interests of the employees }\end{array}$ \\
\hline QT3 & $\begin{array}{l}\text { Everyone cares about bringing the } \\
\text { best to colleagues }\end{array}$ \\
\hline
\end{tabular}

The author here utilizes the set of variables of Saini et al. (2009) to measure the component of ethical climate following benevolence. The set includes three observing variables.

The measurement scale for the component of principle ethical climate includes five observing variables, in which QD1, QD2, and QD3 are inherited from that of Tseng et al. (2011), QD4 and QD5 are selected from the set of Kohlberg (1981). 
Table 4

Observing variables of principle ethical climate

Code Variables

In my bank:

QD1 Those highly recognized are the

QD2 In business, the leaders always expect the employees to follow the regulations and standards of the bank

QD3 In business, we care much about

QD4 Everyone has to consider whether

QD5 The successful ones in my bank are
Sample and data collection procedure

This study is conducted on the sample consisting of employees working in the commercial banks with less than $50 \%$ of state capital. The author does not conduct the research on those of more than $50 \%$ state capital as the two groups are different in history, size of capital, and targeted markets of deposit and credit provision. After having consent, the questionnaires are directly sent to individuals and would be returned within a week. The total number of questionnaires sent are 500 distributed evenly to employees working at branches in HCMC of 33 commercial banks with less than $50 \%$ of state capital. The process of data

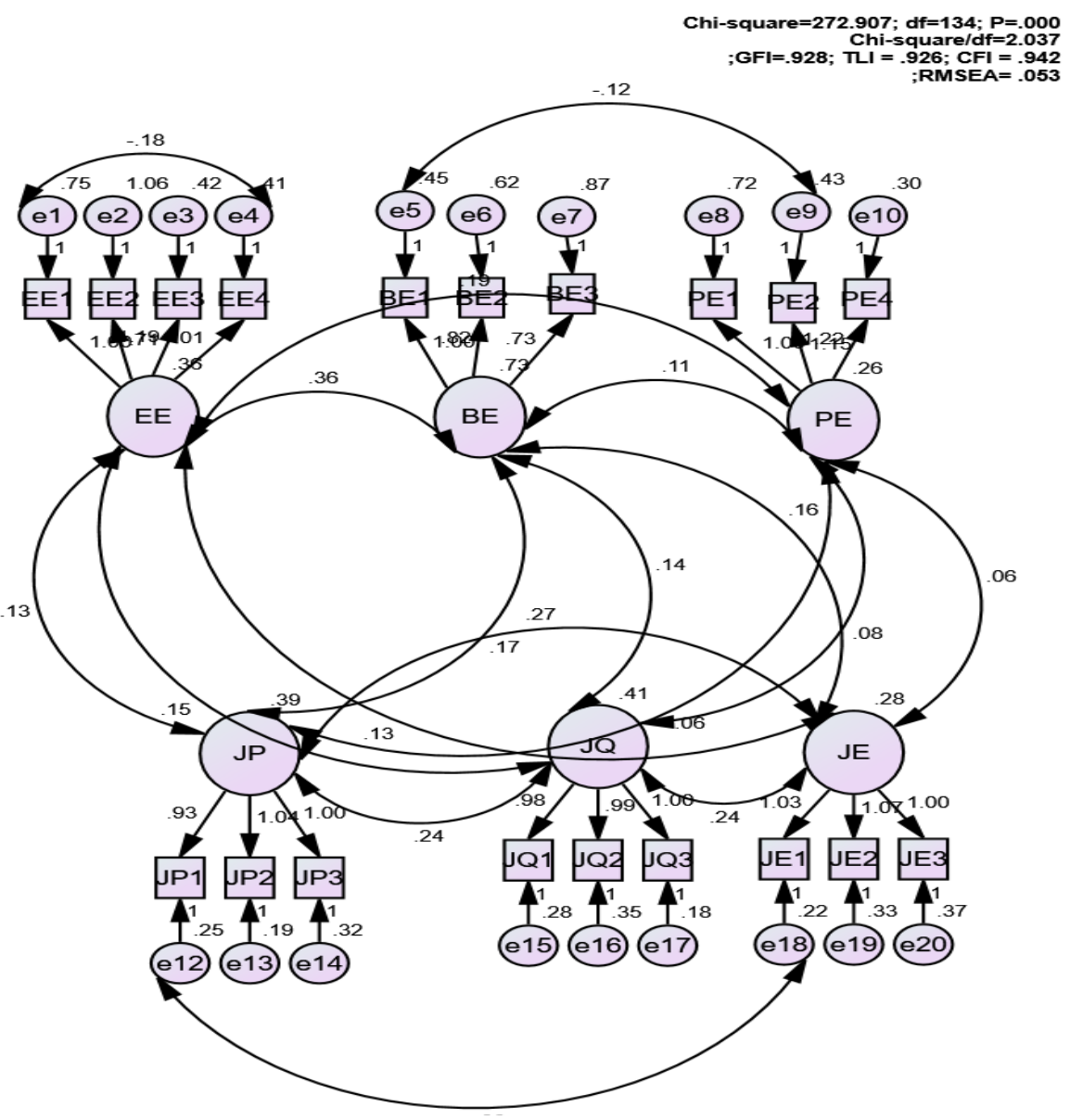

Figure 3. The saturated model 
collection lasted from September to December of 2015 in Ho Chi Minh City. The total of 364 valid complete questionnaires are input into SPSS database for processing.

\section{Results and discussions}

In the step of examining the reliability of the measurement scale by reviewing Cronbach alphas, the observing variables of EE5, BE3, and PE3 are omitted as they have low item-total coefficients. The remaining items in the set of n=364 observations are tested in Confirmatory Factor Analysis. From the outputs of CFA, the items EE2 and PE6 have standardized regression weights of .389 and .461 (<.5). They are then eliminated. The fitness of data is improved after the elimination of EE2 and PE6 with (CMIN/DF) $=2.037$; GFI $=.928 ;$ TLI $=.926$; $\mathrm{CFI}=0.942$;
RMSEA $=0.053$ (Figure 3). The data set is therefore fit for the market. Besides, all the standardized weights $\lambda$ of all observing variables for the research concepts are high enough with significance level of $\mathrm{P}=.000$. Therefore, the measurement scale is acceptable in terms of convergent validity.

From the CFA results of each multidimensional concept (Table 5), the correlation coefficients (r) among the research concepts and standardized deviation are all lower than 1 and have statistical significance ( $p$-value equals to zero). Moreover, the weights of the factors are all greater than 0.5 with statistical significance. Therefore, the measurement scales of the concepts of "business ethical climate" and "individual job performance" have discriminant validity.

\section{Table 5}

Discriminant values

\begin{tabular}{|c|c|c|c|c|c|c|}
\hline & & & $\mathrm{R}$ & SE & CR & $\mathrm{p}$-value \\
\hline $\mathrm{EE}$ & $\longleftrightarrow$ & $\mathrm{BE}$ & 0.36 & 0.049035 & 13.05193 & 0.0000 \\
\hline $\mathrm{BE}$ & $\longleftrightarrow$ & PE & 0.106 & 0.052263 & 17.10588 & 0.0000 \\
\hline JP & $\longleftrightarrow$ & JQ & 0.244 & 0.05097 & 14.83218 & 0.0000 \\
\hline JQ & $\longleftrightarrow$ & $\mathrm{JE}$ & 0.237 & 0.051061 & 14.94279 & 0.0000 \\
\hline $\mathrm{EE}$ & $\longleftrightarrow$ & $\mathrm{JP}$ & 0.134 & 0.052085 & 16.62672 & 0.0000 \\
\hline $\mathrm{EE}$ & $\leftrightarrow$ & JQ & 0.151 & 0.051956 & 16.34069 & 0.0000 \\
\hline $\mathrm{EE}$ & $\longleftrightarrow$ & $\mathrm{JE}$ & 0.13 & 0.052113 & 16.69455 & 0.0000 \\
\hline $\mathrm{BE}$ & $\leftrightarrow$ & JQ & 0.139 & 0.052049 & 16.54223 & 0.0000 \\
\hline $\mathrm{BE}$ & $\longleftrightarrow$ & $\mathrm{JP}$ & 0.167 & 0.051821 & 16.07464 & 0.0000 \\
\hline $\mathrm{BE}$ & $\longleftrightarrow$ & $\mathrm{JE}$ & 0.162 & 0.051865 & 16.15747 & 0.0000 \\
\hline PE & $\longleftrightarrow$ & $\mathrm{JP}$ & 0.056 & 0.052476 & 17.98905 & 0.0000 \\
\hline PE & $\longleftrightarrow$ & JQ & 0.085 & 0.052369 & 17.4723 & 0.0000 \\
\hline PE & $\leftrightarrow$ & $\mathrm{JE}$ & 0.061 & 0.052461 & 17.89903 & 0.0000 \\
\hline $\mathrm{EE}$ & $\leftrightarrow$ & $\mathrm{PE}$ & 0.191 & 0.051591 & 15.68096 & 0.0000 \\
\hline JP & $\leftrightarrow$ & $\mathrm{JE}$ & 0.269 & 0.050622 & 14.4405 & 0.0000 \\
\hline
\end{tabular}

In which: $\mathrm{SE}=\mathrm{SQRT}$ of $\left(1-\mathrm{r}^{\wedge} 2\right) /(\mathrm{n}-2) ; \mathrm{C} \cdot \mathrm{R}=(1-\mathrm{r}) / \mathrm{SE}$ $\mathrm{p}$-value $=$ TDIST $(/ \mathrm{CR} / \mathrm{n}-2,2)$; with $\mathrm{n}$ is the sample size and $\mathrm{n}=364$. 


\section{Table 6}

Reliability validity

\begin{tabular}{|c|c|c|c|c|c|c|c|c|}
\hline Concept & & $\lambda \mathrm{i}$ & $\lambda \mathrm{i}^{\wedge} 2$ & $1-\lambda \mathrm{i}^{\wedge} 2$ & Index & Value & Index & Value \\
\hline \multirow{10}{*}{ ETHICAL CLIMATE } & $\mathrm{EE} 1 \leftarrow \mathrm{EE}$ & 0.57 & 0.32 & 0.68 & & & & \\
\hline & $\mathrm{EE} 2 \leftarrow \mathrm{EE}$ & 0.38 & 0.14 & 0.86 & $\sum\left(\lambda \mathrm{i}^{\wedge} 2\right)$ & 1.48 & $(\rho \mathrm{vc})$ & 0.370 \\
\hline & $\mathrm{EE} 3 \leftarrow \mathrm{EE}$ & 0.74 & 0.54 & 0.46 & $\sum\left(1-\lambda \mathrm{i}^{\wedge} 2\right)$ & 2.52 & Cronbach Alpha & 0.645 \\
\hline & $\mathrm{EE} 4 \leftarrow \mathrm{EE}$ & 0.68 & 0.47 & 0.53 & $\mathrm{bp}\left(\sum \lambda \mathrm{i}\right)$ & 5.62 & $(\rho c)$ & 0.690 \\
\hline & $\mathrm{BE} 1 \leftarrow \mathrm{BE}$ & 0.79 & 0.62 & 0.38 & $\sum\left(\lambda \mathrm{i}^{\wedge} 2\right)$ & 1.37 & Variance extracted ( $\rho v c)$ & 0.458 \\
\hline & $\mathrm{BE} 2 \leftarrow \mathrm{BE}$ & 0.66 & 0.44 & 0.56 & $\sum\left(1-\lambda \mathrm{i}^{\wedge} 2\right)$ & 1.63 & Cronbach Alpha & 0.703 \\
\hline & $\mathrm{BE} 4 \leftarrow \mathrm{BE}$ & 0.56 & 0.31 & 0.69 & $\mathrm{bp}\left(\sum \lambda \mathrm{i}\right)$ & 4.04 & $(\rho c)$ & 0.713 \\
\hline & $\mathrm{PE} 1 \leftarrow \mathrm{PE}$ & 0.52 & 0.27 & 0.73 & $\sum\left(\lambda \mathrm{i}^{\wedge} 2\right)$ & 1.72 & $(\rho \vee c)$ & 0.458 \\
\hline & $\mathrm{PE} 2 \leftarrow \mathrm{PE}$ & 0.67 & 0.45 & 0.55 & $\sum\left(1-\lambda \mathrm{i}^{\wedge} 2\right)$ & 1.72 & Cronbach Alpha & 0.673 \\
\hline & $\mathrm{PE} 4 \leftarrow \mathrm{PE}$ & 0.75 & 0.56 & 0.44 & $\operatorname{bp}\left(\sum \lambda \mathrm{i}\right)$ & 3.76 & $(\rho c)$ & 0.686 \\
\hline \multirow{9}{*}{$\begin{array}{l}\text { JOB } \\
\text { PERFPR-MANCE }\end{array}$} & $\mathrm{JP} 3 \leftarrow \mathrm{JP}$ & 0.74 & 0.55 & 0.45 & $\sum\left(\lambda \mathrm{i}^{\wedge} 2\right)$ & 1.26 & $(\rho v c)$ & 0.631 \\
\hline & $\mathrm{JP} 2 \leftarrow \mathrm{JP}$ & 0.83 & 0.69 & 0.31 & $\sum\left(1-\lambda \mathrm{i}^{\wedge} 2\right)$ & 0.74 & Cronbach Alpha & 0.718 \\
\hline & $\mathrm{JP} 1 \leftarrow \mathrm{JP}$ & 0.76 & 0.57 & 0.43 & $\operatorname{bp}\left(\sum \lambda \mathrm{i}\right)$ & 2.52 & $(\rho c)$ & 0.773 \\
\hline & $\mathrm{JQ} 3 \leftarrow \mathrm{JQ}$ & 0.83 & 0.69 & 0.31 & $\sum\left(\lambda \mathrm{i}^{\wedge} 2\right)$ & 1.80 & $(\rho \mathrm{vc})$ & 0.601 \\
\hline & $\mathrm{JQ} 2 \leftarrow \mathrm{JQ}$ & 0.73 & 0.53 & 0.47 & $\sum\left(1-\lambda \mathrm{i}^{\wedge} 2\right)$ & 1.20 & Cronbach Alpha & 0.821 \\
\hline & $\mathrm{JQ} 1 \leftarrow \mathrm{JQ}$ & 0.76 & 0.58 & 0.42 & $\operatorname{bp}\left(\sum \lambda \mathrm{i}\right)$ & 5.40 & $(\rho c)$ & 0.819 \\
\hline & $\mathrm{JE} 3 \leftarrow \mathrm{JE}$ & 0.66 & 0.43 & 0.57 & $\sum\left(\lambda \mathrm{i}^{\wedge} 2\right)$ & 1.51 & $(\rho v c)$ & 0.504 \\
\hline & $\mathrm{JE} 2 \leftarrow \mathrm{JE}$ & 0.71 & 0.50 & 0.50 & $\sum\left(1-\lambda \mathrm{i}^{\wedge} 2\right)$ & 1.49 & Cronbach Alpha & 0.753 \\
\hline & $\mathrm{JE} 1 \leftarrow \mathrm{JE}$ & 0.76 & 0.58 & 0.42 & $\operatorname{bp}\left(\sum \lambda \mathrm{i}\right)$ & 4.52 & $(\rho c)$ & 0.752 \\
\hline
\end{tabular}

The results in Table 6 indicate that the component concepts of the theoretical model have composite reliability indices greater than the values of Cronbach alphas, except for the measurement scale of "Job efficiency" having Cronbach alpha lower than the composite reliability index by 0.01 . The difference is negligible. Therefore, the measurement scale attains reliability.

The measurement scale, after being checked regarding content validity, convergent validity, discriminant validity, and reliability, is used to test the theoretical model by SEM technique in the AMOS 18 software. SEM ouputs are presented in Figure 4. 


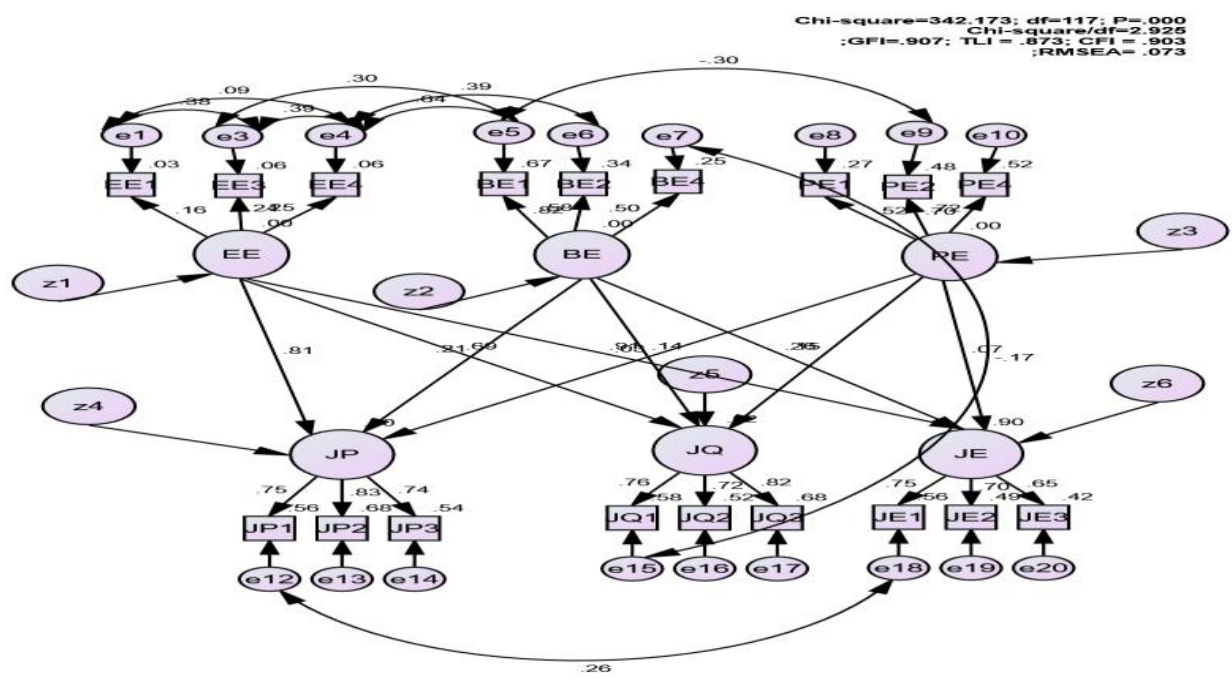

Figure 4. SEM outputs

The indices of CMIN/df $=2.925<3$; RMSEA = $0.073<0.8$; TLI and CFI greater than 0.9 indicate that the model fits the data collected on the market. The estimates (standardized) of the main parameters of the research model are presented in Table 7 . The relationships among the concepts of the model are of significant values $(p<0.05)$. In other words, the nine hypotheses proposed in the model on the relationships among the concepts are all accepted.

\section{Table 7}

Hypotheses test

\begin{tabular}{ccccccc}
\hline & & $\mathrm{R}$ & $\mathrm{SE}$ & $\mathrm{CR}$ & $\mathrm{P}$ value \\
\hline $\mathrm{JP}$ & $\longleftarrow$ & $\mathrm{EE}$ & 0.813 & 0.030603 & 6.110492 & 0.0000 \\
$\mathrm{JQ}$ & $\longleftarrow$ & $\mathrm{EE}$ & 0.693 & 0.037892 & 8.102051 & 0.0000 \\
$\mathrm{JE}$ & $\longleftarrow$ & $\mathrm{EE}$ & 0.911 & 0.021676 & 4.106 & 0.0000 \\
$\mathrm{JP}$ & $\longleftarrow$ & $\mathrm{BE}$ & 0.209 & 0.051398 & 15.38967 & 0.0000 \\
$\mathrm{JQ}$ & $\longleftarrow$ & $\mathrm{BE}$ & 0.142 & 0.052026 & 16.49168 & 0.0000 \\
$\mathrm{JE}$ & $\longleftarrow$ & $\mathrm{BE}$ & 0.258 & 0.050779 & 14.61221 & 0.0000 \\
$\mathrm{JP}$ & $\mathrm{PE}$ & 0.026 & 0.052541 & 18.53788 & 0.0000 \\
$\mathrm{JQ}$ & $\longleftarrow$ & $\mathrm{PE}$ & 0.153 & 0.05194 & 16.30727 & 0.0000 \\
$\mathrm{JE}$ & $\longleftarrow$ & $\mathrm{PE}$ & 0.068 & 0.052437 & 17.77365 & 0.0000 \\
\hline
\end{tabular}




\section{Conclusion and implications}

The statistical analysis results indicate that whether employees perceive the ethical climate at the bank as egoism, benevolence, or principle, these perceptions all help improve their productivity, quality, and productivity. However, the performance of the employees who believe that the climate in their bank is of egoism is much higher than that of the others. The employees would not be missing deadlines or even complete their jobs earlier than planned, reducing the time necessary to complete the jobs, receiving positive feedback from the customers if they feel their banks having ethical climate of egoism. They are also more likely to have ideas or helpful suggestions for the banks. Contrarily, productivity, job quality, and efficiency are nearly under no influence of organizational ethical climate if the employees perceive their ethical climate as principle. Anyway, the results of the qualitative research of Hoang (2015) should also be noted. Commercial banks in Vietnam mostly have the ethical climate of egoism, but it is difficult to distinguish the climates of egoism, benevolence, or principle. It is because no matter it is of egoism or benevolence, all activities of the banks have to comply with the regulations of the controlling organizations and of the bank internally. Moreover, even though managers may perceive the ethical climate in the bank as egoism, there should not be insufficient attention paid to employees' interests, their business partners, and the community. All those cares are for achieving the ultimate goals: the benefits of the bank.

The research confirms the impact of employees' perception on the bank's ethical environment on their individual performance. Although the employees clearly understand their own productivity, quality, and efficiency, they may conveniently overrate these outputs. The incoming research studies may use interviews to understand both the employees' perception of the bank's ethical environment and their supervisors' views on employee's performance. The data would help to conduct better test of the relationships from the research model

\section{References}

Aboelmaged, M. G., \& Subbaugh, S. M. (2012). Factors influencing perceived productivity of Egyptian teleworkers: An empirical study. Measuring Business Excellence, 16(2), 3-22.

Ambrose, M. L., Arnaud, A., \& Schminke, M. (2008). Individual moral development \& ethical climate: The influence of person-organization fit on job attitudes. Journal of Business Ethics, 77, 323-333.

Anantatmula, V. S. (2007). Linking KM effectiveness attributes to organizational performance. VINE: The Journal of Information \& Knowledge Management Systems, 37(2), 133-149.

Bontis, N., \& Serenko, A. (2007). The moderating role of human capital management practices on employee capabilities. Journal of Knowledge Management, 11(3), 31-52.

Carver, L., \& C\&ela, L. (2008). Attaining organizational commitment across different generations of nurses. Journal of Nursing Management, 42(3), 1558-1572.

Chiu, S.-K. (2004). The linkage of job performance to goal setting, work motivation, team building, and organizational commitment in the high-tech industry in Taiwan. In partial fulfillment of the requirements for the degree of Doctor of Business Administration. Nova Southeastern University.

Costigan, R. D., Insinga, R. C., Berman, J. J., Ilter, S. S., Kranas, G., \& Kureshov, V. A. (2006). A cross-culture study of supervisory trust. International Journal of Manpower, 2(8), 764-787. 
Cullen, J. B., Parboteeah, K. P., \& Victor, B. (2003). The effects of ethical climates on organizational commitment: A two-study analysis. Journal of Business Ethics, 46, 127-141.

Cullen, J. B., Victor, B., \& Bronson, J. W. (1993). The ethical climate questionnaire: An assessment of its development and validity. Psychological Reports, 73, 667-674.

Deery, M. (2008). Talent management, work-like balance, and retention strategies. International Journal of Contemporary Hospitality Management, 20(7), 792-806.

Deshpande, S. P. (1996b). The impact of ethical climate types on facets of job satisfaction: An empirical investigation. Journal of Business Ethics, 15, 655-660.

Deshpande, S. P., Joseph, J., \& Shu, X. (2011). Ethical climate and managerial success in China. Journal of Business Ethics, 99(4), 527-534.

Elci, M., \& Alpkan, L. (2009). The impact of perceived organizational ethical climate on work satisfaction. Journal of Business Ethics, 84(3), 297-311.

Gareth and George (1999). Organizational behavior and its implication on employees' performance. Macmillam, Publication limited, London.

Gibbs, T., \& Ashill, N. J. (2013). The effects of high performance work practices on job outcomes. 31(4), 305326. doi:10.1108/IJBM-10-2012-0096.

Goldman, A., \& Tabak, N. (2010). Perception of ethical climate and its relationship to nurses' demographic characteristics and job satisfaction. Nursing Ethic, 17(2), 233-246.

Hartline, M., \& Ferrell, O. C. (1996). The management of customer-contact service employees: An empirical investigation. Journal of Marketing, 16(4), 52-70.

Hoang, H. Y. (2015). Effects of intellectual management on business ethical climate on performance of bank employees (in Vietnamese). Doctoral Thesis. University of Economics HCMC.

Hoepner, A. G., \& Wilson, J. O. S. (2010). Social, environment, ethical and trust (SEET) issue in banking. Retrieved October 15, 2014 from http://sssrn.com/abstrract=1686240.

Icke, B. T., Caliskan, E. N., Ayturk, Y., \& Icke, M. A. (2011). An empirical research of ethical banking in Turkey. Journal of Modern Accounting \& Auditing, 7(3), 289-304.

Jaramillo, F., Mulki, J. P., \& Boles, J. S. (2012). Bringing meaning to the sales job: The effect of ethical climate and customer demandingness. Journal of Business Research, 66(11), 2301-2307.

Jaseviciene, F. (2012). The ethical of banking: Analysis and estimates. Retrieved October 12, 2014 from http://www.vu.lt/leidyba//dokumentai/zurnalai/EKONOMIKA/Ekonomika\%2091\%203 /101-116.pdf

Karatepe, M. O., \& Tekinkus, M. (2010). The effects of work-family conflict, emotional exhaustion and intrinsic motivation on job outcomes of front-line employees. International Journal of Bank Marketing, 24(3), 173193.

Koh, H. C., \& Boo, E. H. Y. (2001). The link between organizational ethics and job satisfaction: A study of managers in Singapore. Journal of Business Ethics, 29, 309-324.

Kohlberg, L. (1981). The philosophy of moral development. Harper \& Row, New York.

Koslowski, P. (2011). The ethics of banking: Conclusions from the financial crisis. Springer.

Kulkarni, U. R., Ravindran, S., \& Freeze, R. (2006-2007). A knowledge management success model: Theoretical development and empirical validation. Journal of Management Information Systems, 23(3), 309-347.

Lim, V., \& Teo, T. (2000). To work or not to work at home: An empirical investigation of factors affecting attitudes towards teleworking. Journal of Managerial Psychology, 15(6), 560-586.

Mayer, D. M., Kuenzi, M., \& Greenbaum, R. I. (2009). Making ethical climate a mainstream management topic: A review, critique, and prescription for the empirical research on ethical climate. In D. De. Cremer (Ed.), 
Psychological perspective on ethical behavior and decision making (pp. 181-213). Information Age Publishing, Greenwich.

Meer, P., \& Ringdal, K. (2009). Flexibility practices, wages and productivity: Evidence from Norway, Personal Review, 38(5), 526-543.

Mulki, J. P., Jaramillo, J. F., \& Locander, W. B. (2008). Effect of ethical climate on turnover intention: Linking attitudinal and stress theory. Journal of Business Ethics, 78, 559-574.

Orpen, C. (1995). Employee job performance and relations with superior as moderators of the effect of appraisal goal setting on employee work attitudes. International Journal of Career Management, 7(2), 3-6.

Saini, A., \& Martin, K. D. (2009). Strategic risk-taking propensity: The role of ethical climate and marketing output control. Journal of Business Ethics, 90(4), 593-606.

Schneider, B., \& Reichers, A. E. (1983). On the etiology of climates. Personal psychology, 36(1), 19-39.

Sims, R. L., \& Keon, T. L. (1997). Ethical work climate as a factor in the development of person-organization fit. Journal of Business Ethics, 16(11), 1095-1105.

Stewart, R. W. (2011). You support diversity, but are you ethical? Examining the interactive effects of diversity and ethical climate perceptions on turnover intentions. Journal of Business Ethics, 99(3), 453-465.

Tsai, M.-T., \& Huang, C. C. (2008). The relationship among ethical climate types, facets of job satisfaction, and the three components of organizational commitment: A study of nurses in Taiwan. Journal of Business Ethics, 80, 565-581.

Tseng, F. C., \& Fan, Y. J. (2011). Exploring the influence of organizational ethical climate on knowledge management. Journal of Business Ethics, 101(2), 325-342.

Victor, B., \& Cullen, J. B. (1988). The organizational bases of ethical work climates. Administrative Science Quarterly, 33(1).

Yavas, U., \& Babakus, E. (2012). Relationship between organizational support, customer orientation and work outcomes: A study of frontline bank employees. International Journal of Bank Marketing, 28(3), $222-238$.

Yavas, U., Babakus, E., \& Karatepe, M. O. (2013). Does hope moderate the impact of job burnout on frontline bank employee's in-role and extra-role performances? International Journal of Bank Marketing, 31(1), 5670 .

Yoon, M, Beatty, S. E., \& Suh, J. (2001). The effect of work climate on critical employee and customer outcomes: An employee level analysis. International Journal of Service Industry Management, 12(5), 500-522. 